\title{
PALEOMAGNETISMO DO NEOPALEOZÓICO DA BACIA SANFRANCISCANA, NOROESTE DE MINAS GERAIS
}

\author{
Daniele Brandt São Bernardo \\ Orientador: Dra. Marcia Ernesto (IAG-USP) \\ 63 p. - Dissertação (Mestrado) - Defesa 10.03.2006
}

\begin{abstract}
RESUMO. A curva de deriva polar aparente para o Paleozóico Superior da América do Sul está baseada em pólos paleomagnéticos obtidos com base em metodologias que não são mais consideradas confiáveis e, portanto, necessita de dados mais bem determinados e com idades mais precisas. $\mathrm{Na}$ Bacia Sanfranciscana (Noroeste de Minas Gerais) afloram rochas sedimentares pertencentes ao Grupo Santa Fé. Estas rochas pertencem ao final do Paleozóico, e constituem um registro glacial compreendendo arenitos, folhelhos e diamictitos, que compõem a Formação Floresta seguida da Formação Tabuleiro. Para o estudo paleomagnético do Grupo Santa Fé amostrou-se arenitos e folhelhos vermelhos de 76 sítios independentes ao Iongo de quatro seções da Formação Floresta: duas seções do Membro Lavado, cada uma com 10 metros de espessura e outras duas do Membro Brejo do Arroz, sendo uma com 0,6 metros e outra com 9 metros de espessura. Após procedimentos detalhados de desmagnetização por campos magnéticos alternados e térmica, foi identificada uma única componente de magnetização muito estável (removida apenas à temperatura de $680^{\circ} \mathrm{C}$ ) cujos portadores são principalmente a hematita e, secundariamente, a magnetita. A magnetização remanente característica apresenta polaridade reversa compatível com o Superchron Reverso do Permo-Carbonífero (260-315Ma) e é de origem primária, como demonstram os testes de campo (comparação com a remanência do embasamento e de seixos pingados), e as evidências de que a hematita formou-se nos estágios iniciais da diagênese. 0 pólo paleomagnético correspondente está situado a 332, $8^{\circ} \mathrm{E}$ e $64,9^{\circ} \mathrm{S}\left(\mathrm{N}=60 ; \alpha_{95}=4,1^{\circ}\right.$; $\left.\mathrm{k}=21\right)$ e representa um pólo de referência para o Paleozóico Superior (260-280Ma). A reconstrução da América do Sul baseada nesse pólo descarta a possibilidade de uma reconstrução alternativa (Pangea B) para explicar as incongruências paleogeográficas apontadas na literatura.
\end{abstract}

ABSTRACT. The apparent polar wander path for Late Paleozoic of South America is based on paleomagnetic poles obtained with methodologies no longer considered reliable. Therefore new poles well determined with better constrained ages are needed. In the Sanfranciscana Basin (Northwest Minas Gerais state) sedimentary rocks from the Santa Fé Group crop out. These rocks correspond to a glacial record of the Late Paleozoic, and lithologies are sandstones, shales and diamictites of the Floresta and Tabuleiro formations. For the paleomagnetic study sandstones and shales were sampled from 76 independent sites throughout four sections of Floresta Formation: two sections (10m thick) from Lavado Member, and two sections of Brejo do Arroz Member ( 0.6 and 9 meters thick). After detailed alternating field and thermal demagnetization procedures a unique characteristic remanence component (erased at $680^{\circ} \mathrm{C}$ ) was identified. Hematite is the main magnetic carrier but magnetite is also present. This characteristic magnetization is of reversed polarity compatible with the Permo-Carboniferous Reversed Superchron (260-315Ma), and is of primary origin as demonstrated by field tests (comparison with remanences of the basement rocks and of dropped stones), and laboratory evidences that hematite formed at initial stages of diagenesis. The corresponding paleomagnetic pole is located at $332.8^{\circ} \mathrm{E}$ and $64.9^{\circ} \mathrm{S}\left(\mathrm{N}=60 ; \alpha_{95}=4.1^{\circ} ; \mathrm{k}=21\right)$, and represents a reference pole for the Late Paleozoic (260-280Ma). Reconstruction of South America based of the Santa Fé pole discard the alternative models (Pangea B) which were conceived to explain incongruencies in paleogeography of Pangea as discussed in literature. 